\title{
Study of Adaptive-Reuse Application in Rumah Atsiri (Ex. Citronella Factory), Karanganyar
}

\author{
Febrione Putri Rakhmanty \\ Department of Architecture, Universitas Tunas Pembangunan, Surakarta, Indonesia \\ febrione.putri@lecture.utp.ac.id \\ Eny Krisnawati \\ Department of Architecture, Universitas Tunas Pembangunan, Surakarta, Indonesia \\ enykrisnawati4@yahoo.com
}

\begin{abstract}
Abandoned and unused old buildings are often seen as a waste of land. One of the ways that old buildings can be reused is to use the adaptive-reuse concept, which is an attempt to reuse an old, unused building into a different function from the original function while maintaining the original building values. The purpose of this research is to understand how the Adaptive Reuse concept is applied in Rumah Atsiri Indonesia. Firstly, the data has been collected through literature survey and field survey. Then, analyzed the elements of Rumah Atsiri Indonesia that can be categorized as adaptive reuse examples and have been investigated in the light of the defined factors. At the end, according to the result we can find what kind of work that has been done in Rumah Atsiri Indonesia that makes it as a sample of adaptive reuse projects. Rumah Atsiri that we see today is the result of the revitalization of an old factory building with a touch of modern architecture. Revitalization is carried out while maintaining the authenticity of the design of the building. The contrass of materials makes visitors able to distinguish which of the old buildings and which buildings and new elements are added by looking at the materials used.
\end{abstract}

Keywords: Adaptive-reuse, sustainable, historical old building, revitalization

\section{Introduction}

Abandoned and unused old buildings are often seen as a waste of land. One of the ways that old buildings can be reused is to use the adaptive-reuse concept, which is an attempt to reuse an old, unused building into a different function from the original function while maintaining the original building values. This concept is mainly used in old, historical buildings that are unused and located in the city center or locations that are visited by many tourists. Adaptive-reuse opens up opportunities for buildings to function more efficiently and sustainably as well as opportunities to preserve historical legacies for future generations. With adaptive-reuse, new job opportunities will also open up for the community (Gao et al, 2020).

Recently, the adaptive-reuse concept has been widely applied as an effort to conserve historical old buildings. One of those that applies this concept is the building of Rumah Atsiri (eng: House of essentials), ex.The Citronella Factory which later became an integrated tourist destination with facilities for aromatic gardens, laboratories, production house, training centers, museums, restaurants, shops, and MICE facilities. The purpose of this research is to understand how the Adaptive Reuse concept is applied in Rumah Atsiri Indonesia. Firstly, the data has been collected through literature survey and field survey. Then, analyzed the elements of Rumah Atsiri Indonesia that can be categorized as adaptive reuse examples and have been investigated in the light of the defined factors. At the end, according to the result we can find what kind of work that has been done in Rumah Atsiri Indonesia that makes it as a sample of adaptive reuse projects.

\section{Adaptive-Reuse}

Adaptive-reuse is an attempt to reuse an old unused building into new functions that are relevant to current needs while maintaining the original values of the building. 
According to Ennis Davis, there are several advantages of adaptive-reuse, including supporting the concept of sustainability, both for the building itself, environmentally, socially, and economically.

According to Rodrigues and Freire (2017, in Gao et al. 2020) adaptive-reuse is the process of strengthening old buildings for new functions. In general, adaptive-reuse application to old buildings is intended for tourism. Therefore, visitor response to adaptive-reuse objects is very important in the success of an adaptive-reuse project.

According to Shao et al (2018, in Susanti et al., 2020), adaptive-reuse is a process of revitalizing or reusing existing structures that already exist, but adapted to new use functions, and adaptive-reuse is also a process of transforming buildings that has become obsolete and ineffective into something new that can be reused for a different purpose. Adaptive - reuse applications that work with historical building structures are more sustainable from an environmental aspect and also minimize costs incurred for development compared to building a new building with new construction.

\section{Adaptive-Reuse in Historical Building}

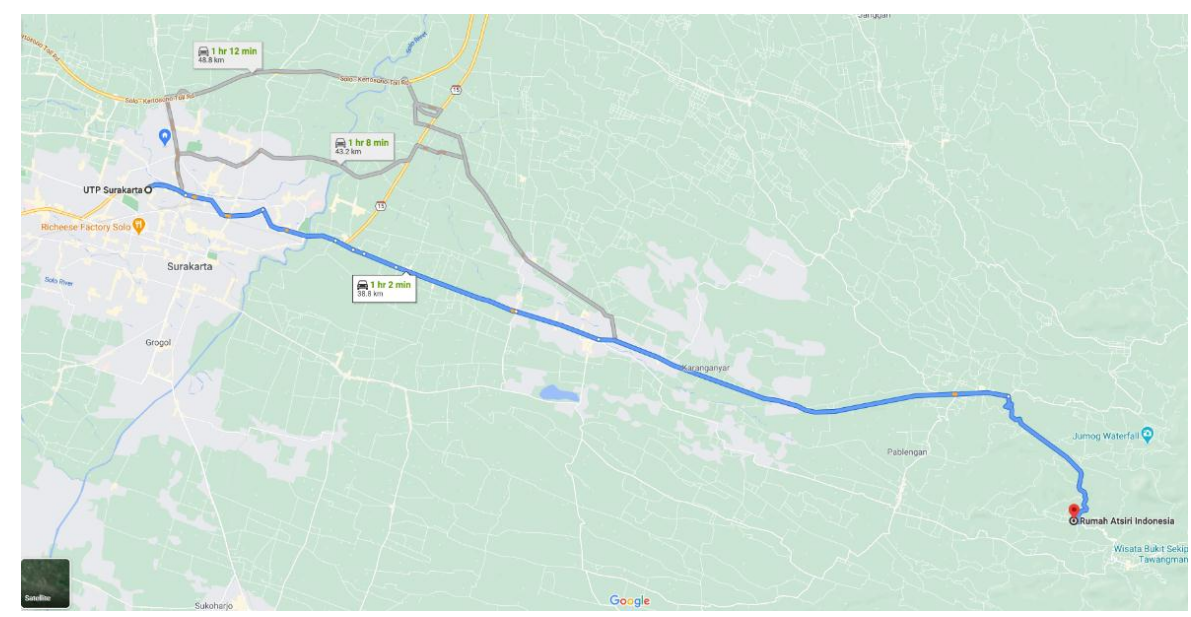

Figure 1: Map of Rumah Atsiri

source: google maps

The old building of Rumah Atsiri was built in 1963-1967 as a form of cooperation between the Indonesian government and the Bulgarian government. After going through a development period of approximately four years, in 1968 the building was opened for the first time and functioned as a Citronella
Plevoets and Cleempoel (2013, in Susanti, 2020) introduced 7 conversion concepts based on the Palimsest metaphor from Machado, including (1) building in it, (2) building on it, (3) building around it, (4) building along the sides, (5) ) adapt to the new function, (6) build by maintaining the style, (7) recycling the remaining material. In the same study, Plevoets and Cleempoel also provide different design strategies in adaptive-reuse applications in historical buildings, namely: (1) physical intervention (2) insertion (3) installation. According to them, the most important and significant factor in adaptive-reuse is the original building.

\section{Rumah Atsiri}

Built on an area of 2.3 hectares, according to their website, Rumah Atsiri is an integrated tourist destination containing aromatic gardens, laboratories, essential oil's production houses, essential oil's training centers, citronella factory museums, restaurants, shops, and MICE (Meeting, Incentive, Convention, and Exhibition) facilities. Rumah Atsiri is located in Plumbon Village, Karanganyar Regency, Central Java, about 35 kilometers east of Surakarta City. 
several times until finally in 2015 it was owned by PT Rumah Atsiri Indonesia.

When it was "rediscovered" in 2015, the condition of the ex.Citronella factory was like any other stalled building. Some corners of the building are damaged with production machines that are not maintained and are missing in several parts. A number of building improvements were made to make the building functional again, however the revitalization or repairs were made to avoid changing the original style of the building which was characterized by a modern architecture. Parts of the building that showed its original function as an essential oil processing plant are also still being preserved, such as the bricks and roster that had been shipped directly from Bulgaria.

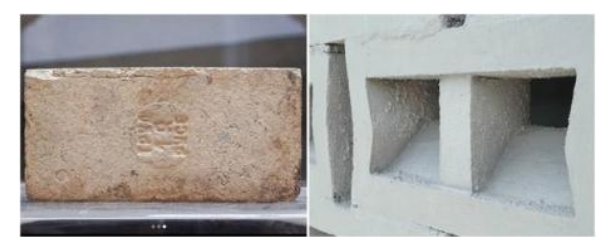

Figure 2: The original brick and roster from Bulgaria is still used in new building concept Credit: personal documentation

The new buildings, which mostly use light steel structures, are made to be connected both in a tourist concept and a visual concept by accentuating the old building with a concrete structure.

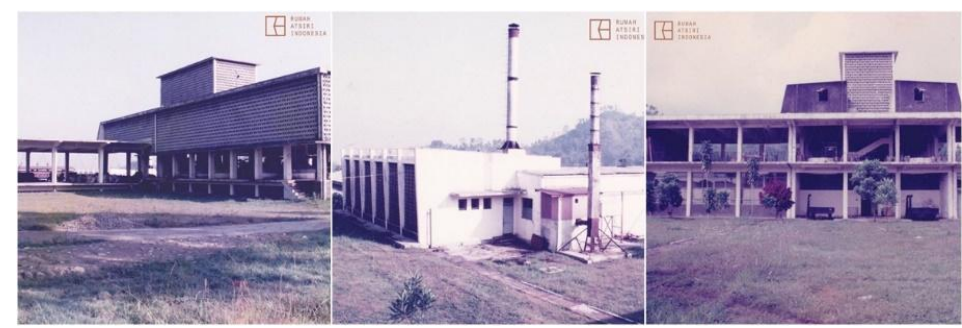

Figure 3: Boiler building and distillation building in 1991 Courtesy of Rumah Atsiri Indonesia



Figure 4: Layout of Rumah Atsiri today Courtesy of Rumah Atsiri Indonesia 


\section{Adaptive Reuse in Rumah Atsiri}

Rumah Atsiri that we see today is the result of the revitalization of an old factory building with a touch of modern architecture. Revitalization is carried out while maintaining the authenticity of the design of the building.

What remains of the Citronella Factory building are the physical buildings of the three refineries, without machines and large tanks. Until now these buildings still stand firmly with the original construction, the addition of new constructions is more about fulfilling new activity functions. The contrast of materials makes visitors able to distinguish which of the old buildings and which buildings and new elements are added by looking at the materials used. Most of the old buildings use iron and concrete, while the new ones use steel, wood and glass.

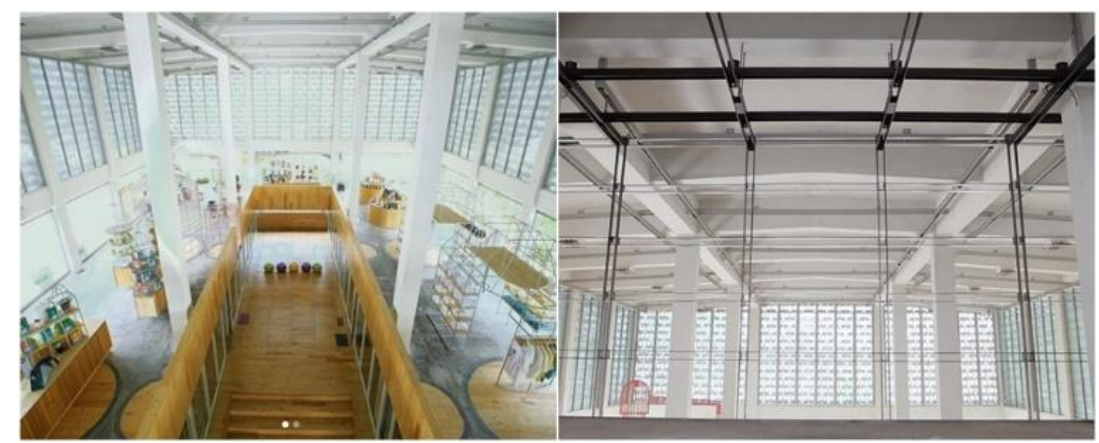

Figure 5: Contrast between old materials and new materials inside Rumah Atsiri Courtesy of Rumah Atsiri Indonesia
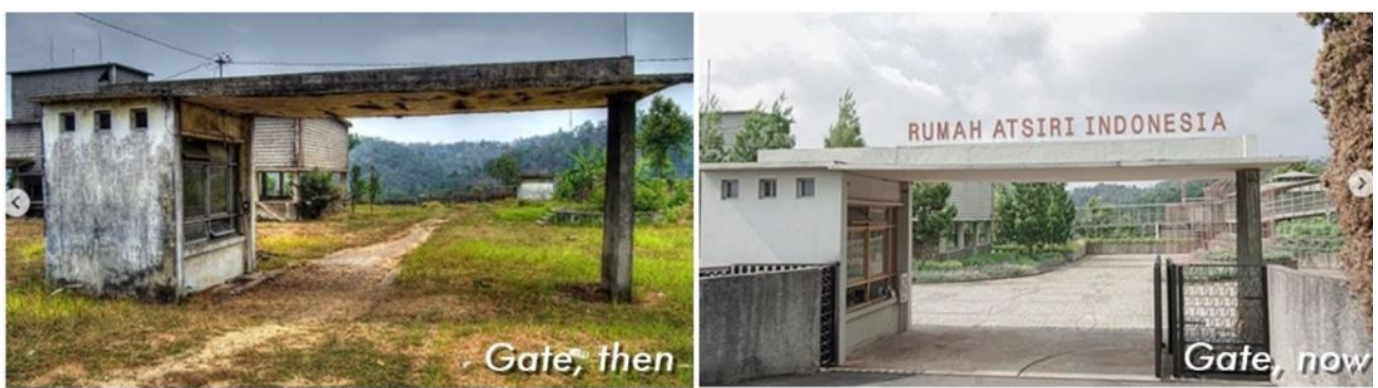

Figure 6: Main gate was a weighbridge back then

Courtesy of Rumah Atsiri Indonesia

Architectural details also play an important role in connecting the old and new buildings. The shape of the paving, the frames on the chairs and columns in the restaurant, the arrangement of plants at the
Marigold Plaza, and the Rumah Atsiri logo itself are adapted from the original roster form of the old building. 


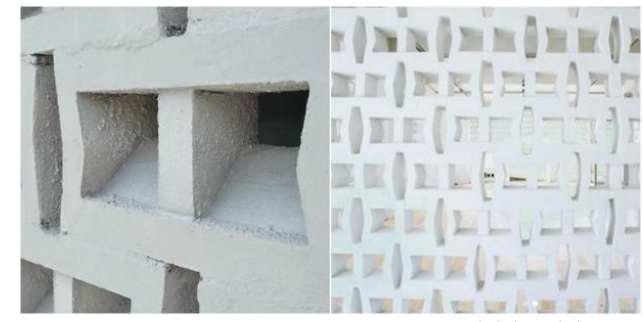

Figure 7: Roster's pattern in old building

Cortesy of Rumah Atsiri Indonesia \& Personal Documentation

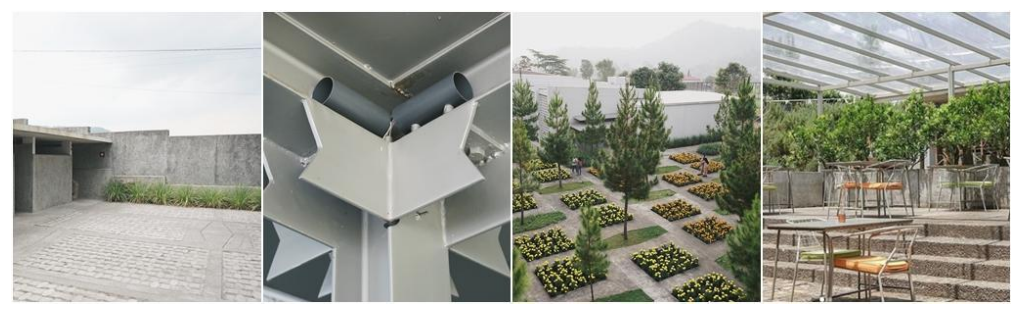

Figure 8: Roster's pattern was adapted in (1)Paving in parking area, (2)Steel column,

(3)Marigold Plaza's arrangement plants, (4)Frame in restaurant's chair

Cortesy of Rumah Atsiri Indonesia \& Personal Documentation

Based on their website, the revitalization of Rumah Atsiri is done using the juxtaposition method (contextual juxtaposition). The original building-that has become the identity of the place-was maintained, but new elements were included without damaging the old building. Today, this area functions as a shop that sells various signature products and souvenirs of Rumah Atsiri Indonesia, while the lower floor is used as a classroom for children to learn about essential oils. The addition of interior and sclupture elements as a sign that the function of space has changed, but still leaves a memory of its old history.
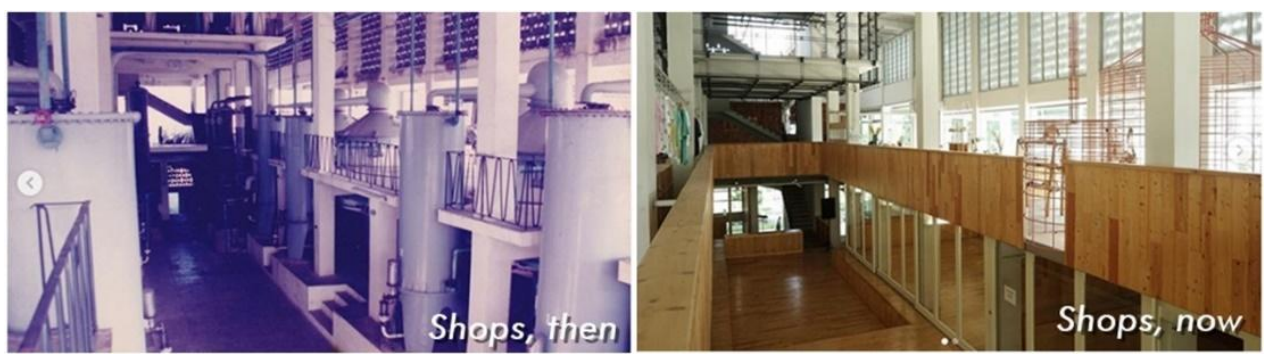

Figure 9: Area for (now) The Shops and classroom was then made for kettle and condenser Courtesy of Rumah Atsiri Indonesia

Paulus Mintarga as the owner of Rumah Atsiri, in his interview with Kompas.com said that the Rumah Atsiri design was based on an old building that was not demolished but was trying to be connected so that it could accommodate new functions. The vision of Rumah Atsiri still refers to its original goal of developing the essential industry in Indonesia through educational tourism.

Rumah Atsiri, seen from its modeling, illustrates how this location shows elements of sustainable tourism. Valerina Daniel, Chair of the Team for the Acceleration of Sustainable Tourism Development, in her report on Kompas.com once explained that sustainable tourism carries 3P elements, namely: People, Planet and Prosperity. Rumah Atsiri shows how this place tries to defend the building from its heretical side. Its existence also seeks to always work together with the village community. According to the manager, around 90 people in the 
surrounding community become employees at Rumah Atsiri. Some local people were trained to make various signature products and souvenirs that are sold in Rumah Atsiri's Shop.

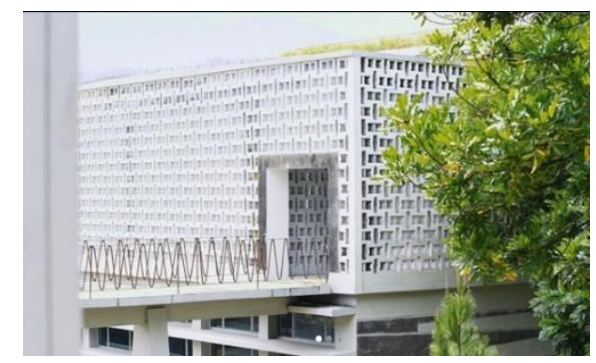

Figure 10: Additional bridge between two buildings in Rumah Atsiri Credit: Personal Documentation

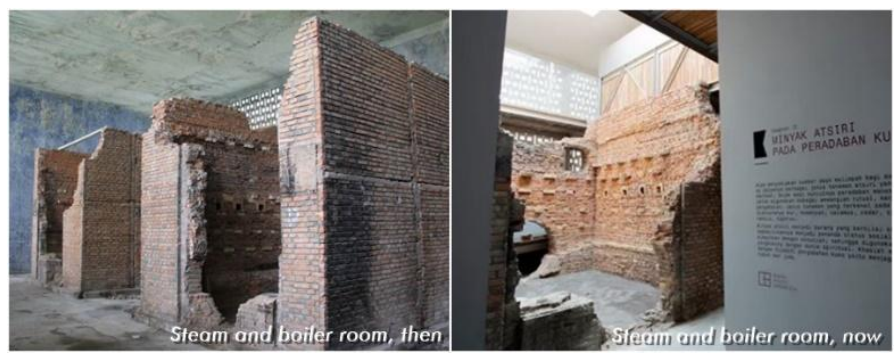

Figure 11: Museum Rumah Atsiri was the Steam and Boiler Room back then Credit: Rumah Atsiri Indonesia

\section{Conclusion}

The concept of adaptive reuse is to embrace the original character, history, and energy of a building and make it relevant to today's needs. If done well, adaptive reuse in historical buildings can provide significant environmental, social, cultural and economic results.

Although it did not explicitly mention the application of the adaptive-reuse concept, we can easily find the characteristics of its application, both tangible and intangible.

In Rumah Atsiri Indonesia, the old and the new are juxtaposed to strengthen one another and to show that development can be done without erasing the history of a place

\section{References}

Articles published in conference proceedings

Susanti, A., Mustafa, M. Y., Wulandari, I. G. (2020). Pemahaman Adaptive Reuse dalam Arsitektur dan Desain Interior sebagai Upaya Menjaga Keberlanjutan Lingkungan: Analisis Tinjauan Literatur. Prosiding Seminar Nasional Desain dan Arsitektur (SENADA). Bali. 2655-2329.
Journal Articles

Hill, S. (2016). Constructive conservation $-a$ model for developing heritage assets. Journal of Cultural Heritage Management and Sustainable Development Vol.6 No.1. DOI 10.1108.

Gao, J., Lin, S., Zhang, C. (2020). Authenticity, involvement, and nostalgia: Understanding visitor satisfaction with an adaptive reuse heritage site in urban China. Journal of Destination Marketing \& Management 15. 100404.

Web sites

Ennis Davis, AICP. (2019). Ten Benefits of Adaptive Reuse [Online] Available: https://www.moderncities.com/article/20 19-jul-ten-benefits-of-adaptivereuse.html [2020, October 24]

Sabrina Santos. (2016). 20 Creative Adaptive Reuse Projects [Online] Available: https://www.archdaily.com/783283/20creative-adaptive-reuse-projects.html [2020, October 24]

Ashley Halsey. (2019). Recognizing The Importance of Adaptive Reuse [Online] Available: 
https://www.buildingenclosureonline.co $\mathrm{m} / \mathrm{blogs} / 14$-the-be-blog/post/88437recognizing-the-importance-of-adaptivereuse.html [2020, October 24]

Nur Rohmi Aida. (2019). Rumah Atsiri, Peninggalan Bung Karmo yang Tak Banyak Diketahui [Online] Available: https://travel.kompas.com/read/2019/08/ 05/071000427/rumah-atsiri-peninggalanbung-karno-yang-tak-banyakdiketahui?page=all [2020, October 26] Rumah Atsiri's official Instagram page. (2020). Available: https://www.instagram.com/rumahatsiri/ [2020, November 10] 